\title{
Sex pheromones as a tool to overcome the Wallacean shortfall in conservation biology: a case of Elater ferrugineus Linnaeus, 1758 (Coleoptera: Elateridae)
}

\author{
Marcin Kadej • Krzysztof Zając • Rafał Ruta • Jerzy M. Gutowski • \\ Dariusz Tarnawski - Adrian Smolis · Tomasz Olbrycht • Adam Malkiewicz • \\ Ewelina Myśków • Mattias C. Larsson · Fredrik Andersson · Erik Hedenström
}

Received: 4 October 2014/ Accepted: 20 November 2014/Published online: 28 November 2014

(C) The Author(s) 2014. This article is published with open access at Springerlink.com

\begin{abstract}
The "Wallacean shortfall"-lack of distributional information-is one of the main problems when trying to assess the threats to and planning conservation strategies for many invertebrate species. Based on published and unpublished records since 1840 , as well as on our own field survey, we attempted to estimate if and to what extent the use of pheromone traps increased the detectability of a rare, saproxylic click beetle Elater ferrugineus. The significant increase in the number of records in 2011-2013 shows that the pheromone method made it much easier to detect the occurrence of the species. Advantages of the pheromone method are that it does not disturb the habitat, can be used by non-specialists, is less costly and less time-consuming, and thus providing a useful tool for conservation research (studying biology, ecology and genetics of local populations).
\end{abstract}

Electronic supplementary material The online version of this article (doi:10.1007/s10841-014-9735-4) contains supplementary material, which is available to authorized users.

M. Kadej $(\bowtie) \cdot$ K. Zając · D. Tarnawski · A. Smolis ·

A. Malkiewicz $\cdot$ E. Myśków

Department of Invertebrate Biology, Evolution and Conservation, Institute of Environmental Biology, Faculty of Biological

Science, University of Wrocław, Przybyszewskiego 63/77,

51-148 Wrocław, Poland

e-mail: marcin.kadej@uni.wroc.pl

R. Ruta

Department of Biodiversity and Evolutionary Taxonomy, Faculty of Biological Science, University of Wrocław, Przybyszewskiego 63/77, 51-148 Wrocław, Poland

J. M. Gutowski

Department of Natural Forests, Forest Research Institute,

17-230 Białowieża, Poland
Keywords Pheromone - Kairomone - Saproxylic insects . New records $\cdot$ Central Europe $\cdot$ Poland

\section{Introduction}

One of the most important problems faced by conservation biologists is insufficient knowledge of distribution of species, not only at the global, but also regional or even local level. The problem, termed the Wallacean shortfall (Lomolino 2004), is especially grave in the case of invertebrates which, in spite of their vast diversity and unquestionably great significance in ecosystems, are to a large extent ignored in conservation studies (Cardoso et al. 2011a). The fact that, compared to vertebrates and flowering plants, they are rarely used for the assessment of biodiversity and for identifying areas that require protection, is usually explained by the time-consuming inventories, high cost and limited number of specialists. Methods of rapid biodiversity assessment, developed in the last decades and based on morphospecies or recognisable

T. Olbrycht

Agroecology Team, Faculty of Biology and Agriculture,

University of Rzeszów, Ćwiklińskiej 1a, 35-601 Rzeszów,

Poland

M. C. Larsson

Department of Plant Protection Biology, Swedish University of

Agricultural Sciences, P.O. Box 102, 23053 Alnarp, Sweden

F. Andersson - E. Hedenström

Eco-Chemistry, Department of Chemical Engineering, Mid

Sweden University, 85170 Sundsvall, Sweden 
taxonomic units (RTU), in which the species richness is estimated without detailed systematic analysis (e.g. Oliver and Beattle 1993; Obrist and Duelli 2010), are supposed to help to overcome such problems. Such studies however deprive us of very valuable information on the occurrence of individual taxa. At the same time, in the case of invertebrates distributional information is usually the only criterion that can be used to assess the extinction risk of a species according to the international criteria (IUCN 2001, 2012, 2014), since data on the population size and abundance trends, as well as on the biology and ecological requirements, are usually very scanty or lacking (Cardoso et al. 2011b). Though the presence of rare and/or endangered species does not necessarily guarantee the representation of overall species diversity (Bonn et al. 2002), they may provide an important basis for the decision in systematic conservation planning (Margules and Pressey 2000). At the same time the problem of "Wallacean shortfall" pertains especially to this group of taxa because of their low detectability in the field, resulting in turn in a small number of records. The species rarity may result either from its small densities in the field, or small efficiency of the selected method of survey. In either case detecting of the species may require increased effort which, in the case of standard, non-selective methods of invertebrate inventory, often based on collecting large samples, may turn out to be unprofitable. For this reason rare species require using more selective methods which increase the probability of their detection. One of the most effective methods of this kind is the use of pheromones or other semiochemicals as attractants. The method has been for a long time used in detection, monitoring and control of pest insects (Kehat and Dunkelblum 1993; Welter et al. 2005; Nadel et al. 2012), including introduced invasive species (Crook et al. 2008; Byers and Naranjo 2014). As demonstrated in recent studies, species-specific and sensitive pheromone-bait traps can be especially useful to detect low-density populations (e.g. Johnson et al. 2006; Kikkert et al. 2006), which makes them an excellent tool for detection of rare and/or endangered species. Despite this, the interest in a wider application of this method in insect conservation and biodiversity studies is still marginal. Pheromones of only few insect species have been identified for future use in the biodiversity conservation (Larsson et al. 2003; Tolasch et al. 2007; Millar et al. 2010; Harvey et al. 2011). Three of them are European red-listed saproxylic beetles (Nieto and Alexander 2010).

Saproxylic beetles are especially difficult to inventory. Standard methods, such as window trapping, pitfall trapping or wood mould sampling (Ranius and Jansson 2002), or else more modern solutions such as vacuum cleaning (Bußler and Müller 2009) or air sampling from tree cavities (Svensson et al. 2003), are very tedious and time- consuming. The results of studies on the use of pheromones are very encouraging and suggest a great usefulness of the method for finding localities of rare species and for monitoring studies in their wide sense (Svensson and Larsson 2008; Larsson and Svensson 2009; Forsmark 2012; Svensson et al. 2012; Musa et al. 2013). An especially high effectiveness of pheromone trapping compared to the standard inventory methods (window/pitfall trapping) has been demonstrated in the case of the red click beetle Elater ferrugineus (Andersson et al. 2014).

In this study we used the pheromone-baited trapping method, in order to determine on a wide spatial (countrywide) and temporal scale to what extent its use could improve the knowledge of the distribution of hardly detectable species, such as Elater ferrugineus, thus becoming an important tool to overcome the "Wallacean shortfall". In parallel with this method used in the field survey, we analysed all the available information on the records of the species (historic and modern, published and unpublished), which made it possible to estimate the efficiency of the pheromone method.

\section{Materials and methods}

\section{Study species}

Elater ferrugineus is a European member of the click beetle family (Elateridae). To date it was known from few and often old records in the western and central parts of the continent (Meržijevskis and Tamutis 2010; Barševskis and Nitcis 2011). Its rarity was explained by its disappearing and thus rare habitat (Svensson et al. 2012): internal mould of old deciduous trees of various species, and hidden life styleimagines are short-lasting and fly high which renders observation difficult (Husler and Husler 1940; Allen 1966; Gurjeva 1979; Alexander 2002; Ranius 2002;Svensson et al. 2004; Tolasch et al. 2007). The larvae of E. ferrugineus spend several years in wood mould. During that time they prey on larvae of other insects, especially scarabaeid beetles (Schimmel 1982; Schimmel and Tarnawski 2010; Barševskis and Nitcis 2011; Andersson 2012).

This species is listed as Endangered in the British Red Data Book (Shirt 1987), in Germany and Sweden, as Vulnerable in Denmark and Poland (Pawłowski et al. 2002, Buchholz and Ossowska 2004; Smolis and Bena 2007), and as Critically Endangered in the Czech Republic (Vávra 2005; Nieto and Alexander 2010).

Distribution data

The analysis included all the available data (both published and unpublished) on the distribution of E. ferrugineus in 
Poland since 1840 . The preliminary list of records was compiled based on the Catalogue of the Fauna of Poland (Burakowski et al. 1985); it was then supplemented with records contained in 26 publications of 1985-2013. In the case of some older contributions, the year of publication was adopted as the date of the record because of the lack of exact date of observation. In order to include unpublished data, we examined the collections of the most important museums in Poland (Museum and Institute of Zoology PAS, Warsaw; Institute of Systematics and Evolution of Animals, Kraków; Natural History Museum, University of Wrocław), and we also sent queries to an array of coleopterists.

Field study

The field survey was carried out in 2011-2013, mainly in south-western Poland (see Appendix 1 of supplementary material). Along with the survey aimed at detection of $E$. ferrugineus with the use of pheromones, we also analysed the results of other, extensive surveys on saproxylic fauna in which pheromones were used. To detect the occurrence of the species we mainly used pheromone traps of windowtrap type. We used sex pheromones of both E. ferrugineus (7-methyloctyl (Z)-4-decenoate [EP] (see in Svensson et al. 2004; Tolasch et al. 2007; Svensson et al. 2012) and of Osmoderma $((\mathrm{R})-(+)-\gamma$-decalactone $)[\mathrm{OP}]$; as the latter pheromone is a kairomone for E. ferrugineus (Svensson et al. 2004; Svensson and Larsson 2008; Barševskis and Nitcis 2011). In this paper we included results of 70 catches in 63 sites where the species was recorded. In $44.3 \%$ of the catches both types of pheromones were used at the same time, placed in separate traps; in the remaining cases only one pheromone was used (see: Table 1). In seven sites catches were conducted during two seasons, in the remaining cases they were carried out only in 1 year.

The traps were installed from the end of June till half of August in various regions of the country, when conducting field studies. During the field work preparatory to this study we conducted the catches till the first individuals of $E$. ferrugineus were caught, but here we also included data from other studies with the use of pheromone traps, in which the catches were continued also after detecting the species. For this reason the exposition time of the traps varied widely among the sites, from 1 to 52 days (Table 1 ). In $81.4 \%$ of the catches we used only one trap (or one set of traps EP and OP) per site, but sometimes the number was greater (see: Table 1). The traps were controlled every 1-2 days, and the trapped beetles were released on site.

A list of all known localities of E. ferrugineus in Poland is downloadable as an Electronic Supplementary Material.

\section{Data analysis}

The distribution map of the species was prepared in QGIS software, ver. 2.4.0-Chugiak (QGIS Development Team 2014), based exclusively on records which contained at least the name of towns or villages. We omitted the records based on general mentions of the occurrence of the species in a more extensive area. Localities were regarded as separate when the distance between them was at least $500 \mathrm{~m}$. To illustrate the increase in the knowledge of the species' distribution in the country, we drew a graph of cumulative number of localities, using records since 1900 which contained information about at least the year of observation. Subsequently, we compared the rate of increase in the number of localities in three periods: 1900-1949, 1950-1999 and 2000-2013; for each period we constructed a multiple regression model based on the cumulative number of localities. The slope $b$ of the regression served as the indicator of the increase rate of the knowledge of the species' occurrence in the country. For the period 2000-2013 separate regression models were constructed for the records made using the pheromone method and without using this method. The differences between the slopes were tested with co-variance analysis (ANCOVA). Additionally we assessed the effectiveness of the pheromone traps based on the time of response of the species to the pheromone used. The parameter for the assessment was the day of pheromone exposition on which

Table 1 Summary trapping statistics for three capture methods used during the study of Elater ferrugineus in 2011-2013

\begin{tabular}{llllr}
\hline $\begin{array}{l}\text { Type } \\
\text { of trap }\end{array}$ & $\begin{array}{l}\text { Number } \\
\text { of catches }\end{array}$ & $\begin{array}{l}\text { Number } \\
\text { of traps }\end{array}$ & $\begin{array}{l}\text { No traps/catch } \\
\text { Mean } \pm \text { SD (min-max) }\end{array}$ & $\begin{array}{l}\text { Exposition time/trap (in days) } \\
\text { Mean } \pm \text { SD (min-max) }\end{array}$ \\
\hline EP & 24 & 33 & $1.38 \pm 0.88(1-4)$ & $5.61 \pm 5.44(1-19)$ \\
OP & 15 & 37 & $2.47 \pm 2.20(1-8)$ & $11.83 \pm 12.67(1-28)$ \\
OP + EP $^{\mathrm{b}}$ & 31 & 37 & $1.19 \pm 0.75(1-4)$ & $5.78 \pm 10.40(1-52)$ \\
All traps & 70 & 107 & $1.53 \pm 1.32(1-8)$ & $7.78 \pm 10.39(1-52)$ \\
\hline
\end{tabular}

$E P$ window trap baited with 7-methyloctyl (Z)-4-decenoate, $O P$ window trap baited with $(\mathrm{R})-(+)-\gamma$-decalactone

a Statistics calculated for 106 traps with known exposition time

b Set of two types of pheromone baited traps (EP and OP) is treated in the statistics as a single trap 
the species was caught for the first time, while the day of placing the trap in the site was adopted as day one. The Kruskal-Wallis test was applied to test the statistical differences between the effectiveness of trapping methods used. Statistical analyses and graphs were performed using R statistical package, version 3.2.1 (R Core Team 2014).

\section{Results}

The existing data included 193 records from 123 localities in the country. Most of them (104) were unpublished field observations. 68 records came from publications; the remaining 17 were based on museum materials. Until recently the species was very rarely recorded in Poland (Fig. 1). Until 2010 the number of records usually did not exceed ten per decade (mean: 5.9 records per decade). The small increase in their number in 1870-1889 was associated with Letzner's $(1871,1889)$ publications. The greater number of observations from 1950-1959 to 1980-1989 (Fig. 1) resulted from the studies of Dr. B. Burakowski in Warsaw and its environs and of Dr. L. Buchholz in the Wielkopolsko-Kujawska Lowland, respectively. After 2000, faunistic studies gained in intensity and brought about another increase in the number of records of $E$. ferrugineus from nearly the whole of the country (Fig. 2). However, the greatest increase dated from 2011 to 2013, when the species was recorded as many as 105 times which was $54.4 \%$ of all the existing records from Poland. The significant increase was the result of introduction of the new method of detection of the species, that is the use of pheromone traps. The proportion of records of $E$. ferrugineus made during those 3 years with the use of this method was $93 \%$.

Overall we recorded 383 capture events of E. ferrugineus with the use pheromone traps during 2011-2013. In more than half of the catches of the species (59.4\%) has been recorded as early as the first day of catching (day of trap suspension). Despite some visible differences in mean days of the first capture event (Table 2), the KruskalWallis test revealed no statistically significant differences in response time of species to pheromone-baited traps between capture methods used $\left(H_{2,69}=2.074\right.$, $P=0.355)$. Also taking into account only the catches with one pheromone-baited trap or a one set of EP and OP used (to eliminate the impact of differences in trapping area), there were no significant differences $\left(H_{2,56}=0.399\right.$, $P=0.819$ ).

The increased number of records was reflected in the increase in the number of localities, as illustrated by the cumulative curve of the number of localities of 1900-2013 (Fig. 3). In the first half of the twentieth century. The increase in the number of localities was small, of only 1.6 locality/10 years. During the next 50 years (1950-1999) the value increased twofold (ANCOVA, $F_{1,96}=85.21$, $P=6.68$ e-15, Fig. 4). In the later period (2000-2013) the rate of locality detection accelerated to reach the mean value of 57.1 localities per decade (ANCOVA, 1900-1949: $F_{1,60}=99.87, P=2.19 \mathrm{e}-14 ; 1950-1999: F_{1,60}=93.83$, $P=7.03 \mathrm{e}-14)$. The result is mainly the effect of the situation of 2011-2013, when on average 22.3 localities were detected per year. When the localities detected with the use of pheromones were not included, the increase rate was distinctly smaller: for the whole period 2000-2013 the

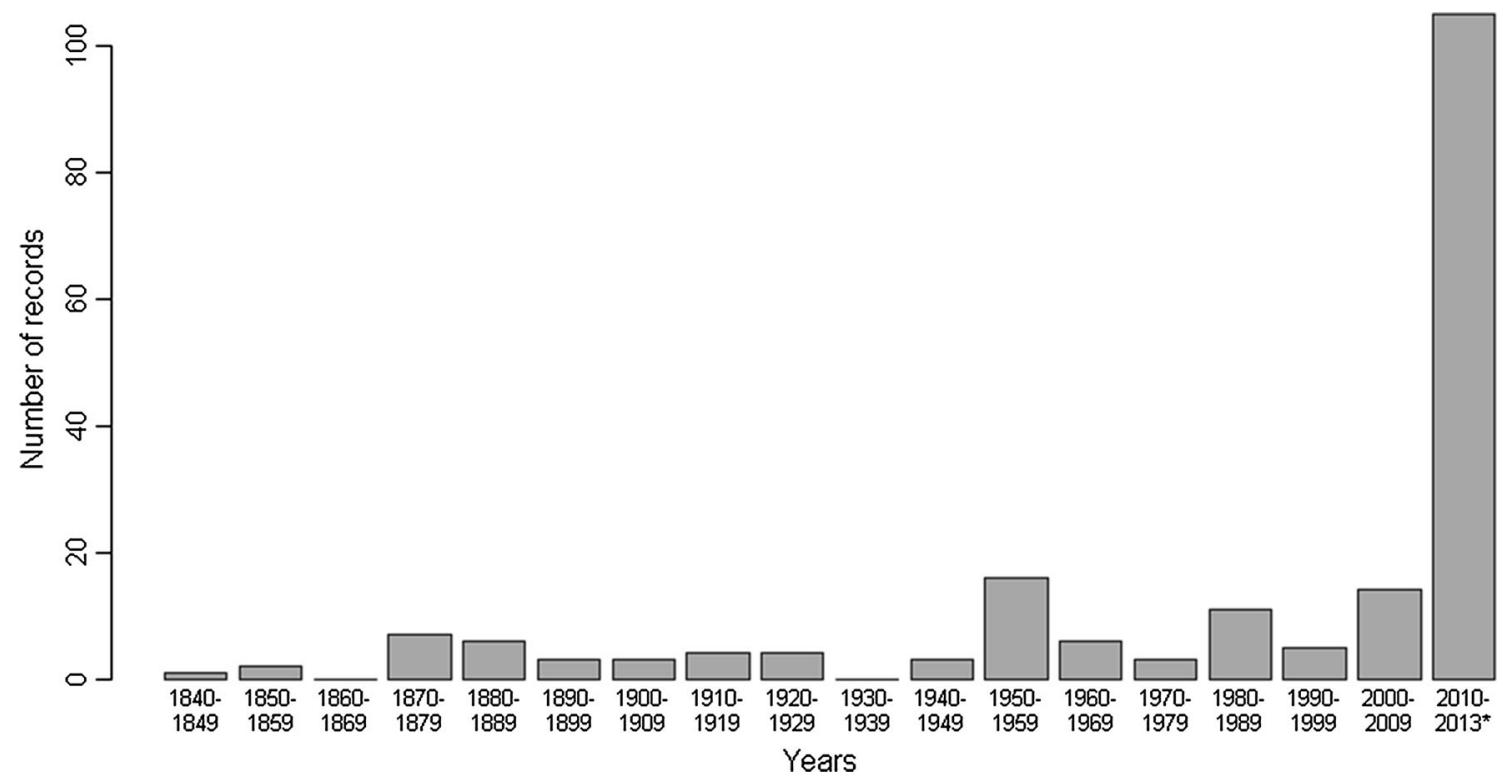

Fig. 1 The number of the records of Elater ferrugineus in Poland in consecutive years between 1840 and 2013 (N = 193). Period shorter than a decade marked with asterisk 
Fig. 2 Map of the cumulative number of localities of Elater ferrugineus in Poland in 1840-2013. Solid circleslocations discovered in the years shows on maps, grey circleslocations discovered in the earlier periods
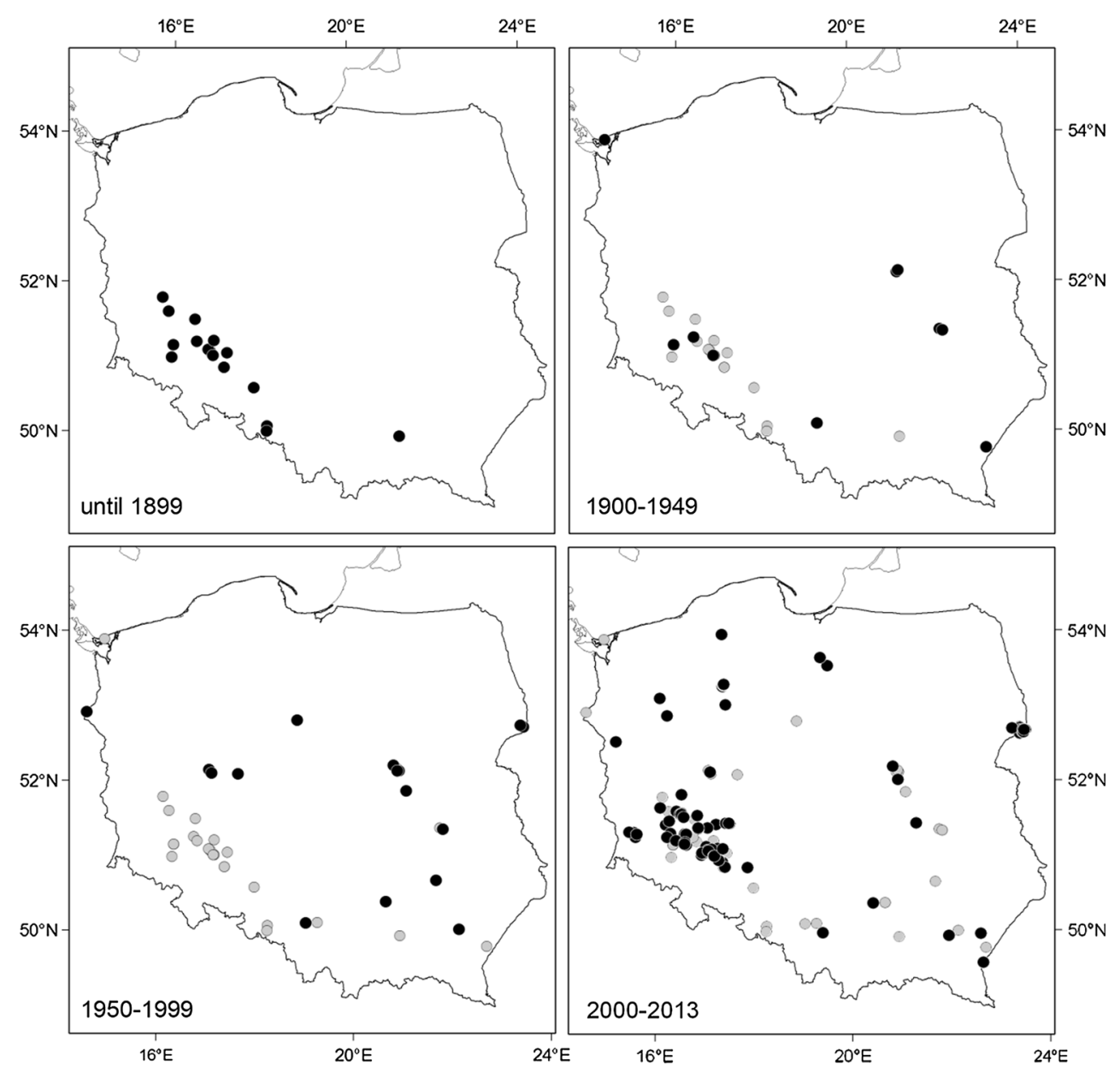

Table 2 Summary of trap efficiency by response time of the Elater ferrugineus for three capture methods. For abbreviations, see Table 1

\begin{tabular}{lll}
\hline Day with first capture event for \\
\hline Type of trap & $\begin{array}{l}\text { All catches }(\mathrm{N}=69) \\
\text { Mean } \pm \text { SD (min-max })\end{array}$ & $\begin{array}{l}\text { Catches with one trap } \\
(\mathrm{N}=56) \text { Mean } \pm \text { SD } \\
(\min -\max )\end{array}$ \\
\hline EP & $2.58 \pm 2.78(1-13)$ & $2.95 \pm 3.03(1-13)$ \\
OP & $1.86 \pm 1.66(1-6)$ & $2.50 \pm 2.00(1-6)$ \\
OP + EP & $3.29 \pm 3.04(1-10)$ & $3.45 \pm 3.08(1-10)$ \\
All traps & $2.75 \pm 2.74(1-13)$ & $3.14 \pm 2.91(1-13)$ \\
\hline
\end{tabular}

mean rate was 12.9 localities/10 years (ANCOVA, $\left.F_{1,24}=10.85, P=0.00305\right)$. Nevertheless, it was still distinctly higher than that observed in 1900-1949 and 1950-1999 (ANCOVA: $\quad F_{1,60}=464.4, \quad P<2 \mathrm{e}-16$; $F_{1,60}=205.9, P<2 \mathrm{e}-16$, respectively, Fig. 4$)$.

Conclusions and implications for conservation

The increase in the number of records of E. ferrugineus in 2000-2009 is most probably associated with Poland joining the EU and the resulting increased interest in species which are of importance for the Union (Gutowski and Przewoźny 2013), especially Osmoderma eremita s. lato. Because of the co-occurrence of the two species in the same habitats, surveying $O$. eremita made it possible to detect also $E$. ferrugineus. This was confirmed by the significant increase (compared to the preceding periods) in the number of new localities of E. ferrugineus in 2007, when also many new areas inhabited by $O$. eremita were discovered, mainly because of the inventory of species listed in the Annexes of the Habitat Directive, carried out in Polish State Forests (Oleksa 2009).

Considering the earlier knowledge of the occurrence of the species, it can be seen that the localities discovered after 2011 were mostly situated within areas of the species' known distribution. This means that the increased number of records is associated with the improved detectability of the species due to the use of the pheromone method, and not with an increase in the country's population of Elater ferrugineus. It can thus be suspected that the previous assessments of the population of E. ferrugineus were grossly underestimated, and the species is much more common in Poland than formerly believed; it may have 
Fig. 3 Increase in the cumulative number of localities of Elater ferrugineus in 1900-2013 ( $\mathrm{N}=108$ localities), without and with the use of pheromone-baited traps
Fig. 4 Multiple regression models for three periods. The period after 2000 was divided in terms of the use of pheromonebait traps. Regressions: 1900-1949, y $=0.176 \mathrm{x}-$ $0.437\left(\mathrm{R}^{2}=0.94\right) ; 1950-1999$, $\mathrm{y}=0.293 \mathrm{x}+0.575$

$\left(\mathrm{R}^{2}=0.94\right) ; 2000-2013$, without pheromone, $\mathrm{y}=1.484 \mathrm{x}-3.055$ $\left(\mathrm{R}^{2}=0.94\right) ; 2000-2013$, with pheromone, $\mathrm{y}=5.026 \mathrm{x}-$ $19.626\left(\mathrm{R}^{2}=0.65\right)$. All regressions are significant at $P<0.001$
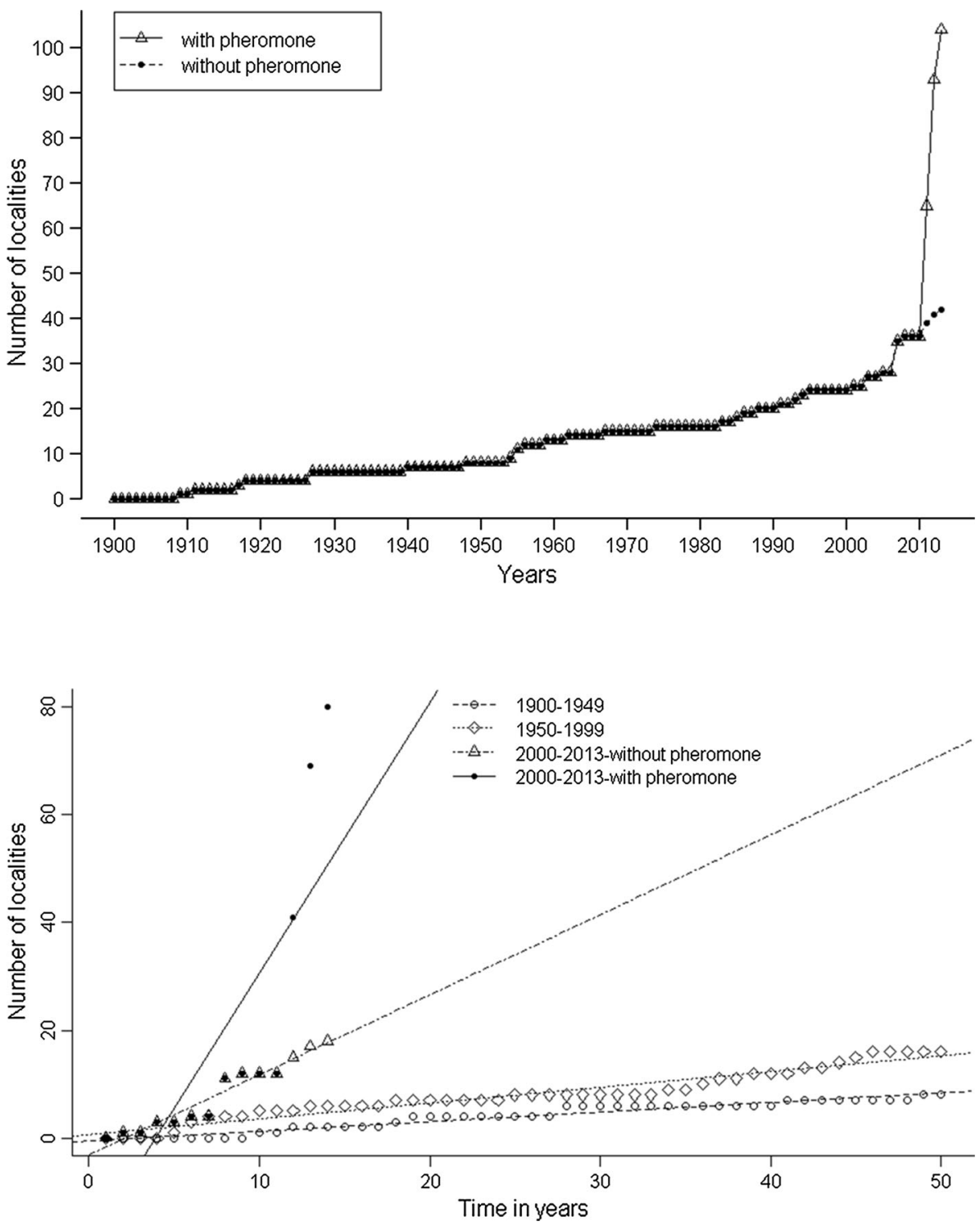

been overlooked during field surveys because of its low detectability. This is confirmed by its new records in southwestern Poland. Many of the new localities coincide with places of historic records of the nineteenth and early twentieth century (Fig. 2), which till recently were the only ones in that part of the country (Smolis and Bena 2007). This reflects the low detectability of the species with conventional methods and the probable continuity of local populations which has hitherto gone undetected.

The main advantage of the use of pheromones is the non-invasive character of the method. Exploration of wood mould, and thus disturbance of this sensitive system, can be avoided; the method reduces both the time required for the survey and the cost. The method can be used by non- specialists with basic training-installing traps and identifying imagines do not present a problem. A disadvantage, compared to the traditional methods of collecting E. ferrugineus, is the impossibility to obtain information on the location of the wood mould from which the beetles come. This, however, is not important in surveys aimed at selection of forest patches with a rich insect fauna and continuously functioning ecosystem.

The use of pheromones which attract imagines eliminates the need to engage a specialist who would be indispensable to identify larvae or pupae. The advantages of using pheromones for E. ferrugineus open new perspectives for scientists and create an array of research possibilities (not feasible before the discovery of the pheromone 
because of the small detectability). The use of pheromone traps makes the study of local populations in relation to their biology, ecology or genetics (phenology of the species, habitat preferences, dispersal potential, populations genetics, degree of isolation etc.) possible. A short-term use of the pheromone (here and now) guarantees catching only individuals from the nearest vicinity (and thus local population).

As shown by our results, no doubt the use of pheromones (both sex pheromones and methods based on the principle of kairomone response) is one of the most effective, simplest and least cheaply methods of overcoming the "Wallacean shortfall". Further studies on the possibility to use similar solutions (effective inventory methods) for other species, equally difficult to detect, are necessary.

The results of our study indicate that depending on which scientific method is used, it can significantly improve overcoming "Wallacean shortfall", next to other solutions proposed by Cardoso et al. (2011a). Using pheromones is worth considering, as one of the most effective, simplest and least cheaply (regarding to the total cost in economical meaning but also time-consuming) method for E. ferrugineus. The same method could be used to research other little known species and equally difficult to detect (e.g. Limoniscus violaceus or Buprestis splendens).

Acknowledgments Our sincerely thanks go to our colleagues (Waldemar Bena, Ewa Ryszarda Kamińska, Michał Klawiński, Andrzej Melke, Jacek Mazepa, Tomasz Mokrzycki, Barbara Myśków, Jacek Sarnowski, Szczepan Polus, Marlena Zawisza and Katarzyna Zwierzchlewska) for assistance in the field study (collecting data). This research was supported by the Department of Invertebrate Biology, Evolution and Conservation, Institute of Environmental Biology, Faculty of Biological Science, University of Wrocław (project no. 1076/IBŚ/2014).

Open Access This article is distributed under the terms of the Creative Commons Attribution License which permits any use, distribution, and reproduction in any medium, provided the original author(s) and the source are credited.

\section{References}

Alexander KNA (2002) The invertebrates of living and decaying timber in Britain and Ireland-a provisional annotated checklist. English Nature, Peterborough

Allen AA (1966) The rarer Sternoxia (Col.) of Windsor Forest. Entomol Rec 78:14-23

Andersson K (2012) Pheromone-based monitoring of Elater ferrugineus as an indicator for species-rich hollow oak stands, dissertation, fakulteten för landskapsplanering, trädgårds- och jordbruksvetenskap, pp 39

Andersson K, Bergman KO, Andersson F, Hedenström E, Jansson N, Burman J, Winde I, Larrson MC, Milberg P (2014) Highaccuracy sampling of saproxylic diversity indicators at regional scales with pheromones: the case of Elater ferrugineus
(Coleoptera, Elateridae). Biol Conserv 171:156-166. doi:10. 1016/j.biocon.2014.01.007

Barševskis A, Nitcis M (2011) Elater ferrugineus Linnaeus, 1758 (Coleoptera: Elateridae) - a new species for the fauna of Latvia. Baltic J Coleopterol 11(2):187-195

Bonn A, Rodrigues ASL, Gaston KJ (2002) Threatened and endemic species: are they good indicators of patterns of biodiversity on a national scale? Ecol Lett 5:733-741. doi:10.1046/j.1461-0248. 2002.00376.x

Buchholz L, Ossowska M (2004) Elater ferrugineus Linnaeus, 1758. Tęgosz rdzawy. In: Głowaciński Z., Nowacki J. Polish red data book of animals. Invertebrates. Institute of Nature Conservation PAS and The August Cieszkowski Agricultural University of Poznań, p 119-120

Burakowski B, Mroczkowski M, Stefańska J (1985) ChrząszczeColeoptera. Buprestoidea, Elateroidea i Cantharoidea. Katalog fauny Polski. PWN, Warszawa, 23(10):401

Bußler H, Müller J (2009) Vacuum cleaning for conservationists: a new method for inventory of Osmoderma eremita (Scop., 1763) (Coleoptera: Scarabaeidae) and other inhabitants of hollow trees in Natura 2000 areas. J Insect Conserv 13:355-359. doi:10.1007/ s10841-008-9171-4

Byers JA, Naranjo SE (2014) Detection and monitoring of pink bollworm moths and invasive insects using pheromone traps and encounter rate models. J App Ecol. doi:10.1111/1365-2664. 12270

Cardoso P, Erwin TL, Borges PAV, New TR (2011a) The seven impediments in invertebrate conservation and how to overcome them. Biol Conserv 144:2647-2655. doi:10.1016/j.biocon.2011. 07.024

Cardoso P, Borges PAV, Triantis KA, Ferrández MA, Martín JL (2011b) Adapting the IUCN red list criteria for invertebrates. Biol Conserv 144:2432-2440. doi:10.1016/j.biocon.2011.06.020

Crook DJ, Khrimian A, Francese JA, Fraser I, Poland TM, Sawyer AJ, Mastro VC (2008) Development of a host based semiochemicals lure for trapping emerald ash borer Agrilus planipennis (Coleoptera: Buprestidae). Environ Entomol 37:356-365

Forsmark B (2012) Elater ferrugineus and Osmoderma eremita, a regional survey and habitat requirements on different landscape scales, Självständigt arbete vid LTJ-fakulteten, SLU, Kandidatarbete 15 HP, Alnarp 2012, pp 37

Gurjeva EL (1979) Zhuki-Shtshelkuny (Elateridae); Podsemejstvo Elaterinae; Triby Megapenthini, Physorhinini, Ampedini, Elaterini, Pomachiliini. Fauna SSSR, Zhestkokrylyje Tom XII vyp 4:1-452

Gutowski JM, Przewoźny M (2013) Program NATURA 2000 jako narzędzie ochrony chrząszczy (Coleoptera) w Polsce. Wiad Entomol 32 (Suppl: 5-40)

Harvey DJ, Hawes CJ, Gange AC, Finch P, Chesmore D, Farr I (2011) Development of non-invasive monitoring methods for larvae and adults of the stag beetle, Lucanus cervus. Insect Conserv Divers 4:4-14. doi:10.1111/j.1752-4598.2009.00072.x

Husler F, Husler J (1940) Studien über die Biologie der Elteriden. Mitt Münch Entomol Ges 30(1):343-397

IUCN (2001) IUCN red list categories and criteria. Version 3.1. IUCN Species Survival Comission, Gland, Switzerland and Cambridge, UK

IUCN (2012) IUCN red list categories and criteria: Version 3.1. 2nd edn. Gland, Switzerlandand Cambridge, UK. www.iucnredlist. org/technical-documents/categories-and-criteria. Accessed 30 Jun 2014

IUCN Standards and Petitions Subcommittee (2014) Guidelines for using the IUCN red list categories and criteria. Version 11. Prepared by the standards and petitions subcommittee http:// www.iucnredlist.org/documents/RedListGuidelines.pdf. Accessed 30 Jun 2014 
Johnson DM, Liebhold AM, Tobin PC, Bjornstad ON (2006) Allee effects and pulsed invasion by the gypsy moth. Nature 444(7117):361-363

Kehat M, Dunkelblum E (1993) Sex pheromones: achievements in monitoring and mating disruption of cotton pests in Israel. Arch Insect Biochem Physiol 22:425-431. doi:10.1002/arch. 940220310

Kikkert JR, Hoepting CA, Wu Q, Wang P, Baur R, Shelton AM (2006) Detection of Contarinia nasturtii (Diptera: Cecidomyiidae) in New York, a new pest of cruciferous plants in the United States. J Econ Entomol 99(4):1310-1315. doi:10.1603/00220493-99.4.1310

Larsson MC, Svensson GP (2009) Pheromone monitoring of rare and threatened insects: exploiting a pheromone-kairomone system to estimate prey and predator abundance. Conserv Biol 23:1516-1525

Larsson MC, Hedin J, Svensson GP, Tolasch T, Francke W (2003) Characteristic odor of Osmoderma eremita identified as a malereleased pheromone. J Chem Ecol 29:575-587. doi:10.1023/A: 1022850704500

Letzner K (1871) Verzeichniss der Käfer Schlesiens. Z Ent Breslau NF, 2, XXIV+ pp 328

Letzner K (1889) Fortsetzung des Verzeichnisses der Käfer Schlesiens. Z Ent Breslau NF 14:237-284

Lomolino MV (2004) Conservation biogeography. In: Lomolino MV, Heaney LR (eds) Frontiers of Biogeography: new directions in the geography of nature. Sinauer Associates, Sunderland, Massachusetts, pp 293-296

Margules CR, Pressey RL (2000) Systematic conservation planning. Nature 405:243-253. doi:10.1038/35012251

Meržijevskis A, Tamutis V (2010) Elater ferrugineus Linnaeus, 1758-a new species for Lithuania. Acta Zool Lituan 20(4):242-245

Millar JG, McElfresh JS, Romero C, Vila M, Mari-Mena N, LopezVaamonde C (2010) Identification of the sex pheromone of a protected species, the Spanish moon moth Graellsia isabellae. J Chem Ecol 36:923-932. doi:10.1007/s10886-010-9831-1

Musa N, Andersson K, Burman J, Andersson F, Hedenström E, Jansson N, Paltto H, Westerberg L, Winde I, Larsson MC, Bergman K-O, Milberg P (2013) Using sex pheromone and a multi-scale approach to predict the distribution of a rare saproxylic beetle. PLoS One 8(6):be66149. doi:10.1371/jour nal.pone. 0066149

Nadel RL, Wingfield MJ, Scholes MC, Lawson SA, Slippers B (2012) The potential for monitoring and control of insect pests in Southern Hemisphere forestry plantations using semiochemicals. Ann For Sci 69:757-767. doi:10.1007/s13595-012-0200-9

Nieto A, Alexander KNA (2010) European Red List of Saproxylic Beetles. Publications Office of the European Union, Luxembourg

Obrist MK, Duelli P (2010) Rapid biodiversity assessment of arthropods for monitoring average local species richness and related ecosystem services. Biodivers Conserv 19:2201-2220. doi:10.1007/s10531-010-9832-y

Oleksa A (2009) Conservation and ecology of the hermit beetle Osmoderma eremita s. 1. in Poland. In: Buse J, Alexander KNA, Ranius T, Assmann T (eds.) Saproxylic beetles-their role and diversity in European woodland and tree habitats. Proceedings of the 5th Symposium and Workshop on the Conservation of Saproxylic Beetles. Pensoft Series Faunistica, 89:177-188

Oliver I, Beattle J (1993) A possible method for the rapid assessment of biodiversity. Conserv Biol 7:562-568. doi:10.1046/j.15231739.1993.07030562.x
Pawłowski J, Kubisz D, Mazur M (2002) Coleoptera. The beetles. In: Z.Glowacinski (ed.) Red list of threatened animals in Poland. Supplement, pp 88-110

QGIS Development Team (2014) QGIS Geographic Information System. Open Source Geospatial Foundation Project. http://qgis. osgeo.org. Accessed 30 Jun 2014

R Core Team (2014) R: a language and environment for statistical computing. R Foundation for Statistical Computing, Vienna, Austria. http://www.R-project.org/. Accessed 30 Jun 2014

Ranius T (2002) Population ecology and conservation of beetles and pseudoscorpions living in hollow oaks in Sweden. Anim Biodiv Conserv 25(1):53-68

Ranius T, Jansson N (2002) A comparison of three methods to survey saproxylic beetles in hollow oaks. Biodivers Conserv 11:17591771. doi:10.1023/A:1020343030085

Schimmel R (1982) Zur Biologie des Rostgoldenen Mulm-Schellkafers Elater ferrugineus mit besonderer Berucksichtigung seines Vorkommens in der sudwestpfalzischen Grenzregion Coleoptera: Elateridae. Mitt der Pollichia des Pfaelzischen Ver Fuer Naturkunde und Naturschutz 70:199-215

Schimmel R, Tarnawski D (2010) Monograph of the subtribe Elaterina (Insecta: Coleoptera: Elateridae: Elaterinae). Genus 21(3):325-487

Shirt DB (1987) British red data books. Volume 2, Insects. Peterborough, UK: Nature Conservancy Council

Smolis A, Bena W (2007) Współczesne dane o występowaniu na Dolnym Śląsku sprężyka rdzawego Elater ferrugineus Linnaeus, 1758 (Coleoptera: Elateridae). Przyr Sudet 10(2007):155-156

Svensson GP, Larsson MC (2008) Enantiomeric specificity in a pheromone-kairomone system of two threatened saproxylic beetles, Osmoderma eremita and Elater ferrugineus. J Chem Ecol 34:189-197. doi:10.1007/s10886-007-9423-x

Svensson GP, Larsson MC, Hedin J (2003) Air sampling of its pheromone to monitor the occurrence of Osmoderma eremita, a threatened beetle inhabiting hollow trees. J Insect Conserv 7:189-198. doi:10.1023/B:JICO.0000020896.71333.f6

Svensson GP, Larsson MC, Hedin J (2004) Attraction of the larval predator Elater ferrugineus to the sex pheromone of its prey, Osmoderma eremita, and its implication for conservation biology. J Chem Ecol 30:353-363. doi:10.1023/B:JOEC. $0000017982.51642 .8 \mathrm{c}$

Svensson GP, Liedtke C, Hedenström E, Breistein P, Bång J, Larsson MC (2012) Chemical ecology and insect conservation: optimizing pheromone-based monitoring of the threatened saproxylic click beetle Elater ferrugineus. J Insect Conserv 16:549-555. doi:10.1007/s10841-011-9440-5

Tolasch T, Von Fragstein M, Steidle JLM (2007) Sex pheromone of Elater ferrugineus L. (Coleoptera: Elateridae). J Chem Ecol 33:2156-2166. doi:10.1007/s10886-007-9365-3

Vávra JC (2005) Elateridae. In: J. Farkač, D. Král and M. Škorpík (eds) List of threatened species in the Czech Republic. Invertebrates, pp 469-473. Praha: Agency of nature conservation and landscape protection of the CR. [Vavrá, J. C. 2005. Elateridae. V: J. Farkač, D. Král, M. Škorpík (eds) Červený seznam ohrožených druhů České republiky. Bezobratlí, pp 469-473. Praha: Agentura ochrany přírody a krajiny ČR.]

Welter SC, Pickel C, Millar J, Cave F, van Steenwyk RA, Dunley J (2005) Pheromone mating disruption offers selective management options for key pests. Calif Agric 59(1):16-22. doi:10. 3733/ca.v059n01p16 